\title{
CORRUPTION IN THE EXTRACTIVE INDUSTRY SECTOR REINVENTING TRUSTED GOVERNANCE "IRAQI CASE"
}

\author{
Paiman Ahmad ${ }^{1}$
}

\begin{abstract}
In the natural resource governance, corruption and transparency both got high attraction from the public and worldwide institutions, which focus on transparency, corruption and good governance. Tackling corruption in extractive industry in countries endowed with natural resources is the core concern for the people, yet governments in most developing countries are not concerned about being prepared for the transparency and accountability initiatives for creating open governments. This study offers a review existing literature aiming at evaluating the impact of E-Government for transparency and accountability in the extractive industry sector in Iraq since 2003. In fact, the natural resource governance needs good governance principles to be enforced for improving transparency and accountability between the government and the companies during, licensing, exploration, contracting, extraction, revenue generation and the allocation process of the revenues. While, E- Governance has got international attention from developed and developing countries, the initiative started with Kimberly Process Certification Scheme (KPCS), followed by the Global Witness/ Publish What You Pay Coalition (PWYP), with the recent emergence of the Extractive Industries Transparency Initiative (EITI). Many resource abundant countries such as Iraq, Nigeria, Venezuela, Angola, etc, underperform in terms of socio-economic development, those countries face the 'the resource curse' as an economic phenomenon, which is interlinked to the politics of resource governance. Indeed, corruption and transparency as the main principles of pure governance in natural resources set the picture of government for being accountable for his populations. This study aims in answering this thesis:
\end{abstract}

In the absence of E-Government, corruption hampered the revenues in Iraq similarly as many other rentier states

Key words: Iraq, Extractive Industry, Corruption, E-Governance, Transparency

\section{Introduction}

Corruption has got intensive literature; for the purpose of this study corruption is defined as "principally a governance issue - a failure of institutions and a lack of capacity to manage society by means of a framework of social, judicial, political and economic checks and balances." [UNDP, 2006]. Comparably, the World Bank (1997) defined corruption as "the misuse or the abuse of public office for private gain." According to the United Nations Convention against corruption (2004) noted "corrupt officials will in future find fewer ways to hide their illicit gains, especially in the developing countries where corrupt official have plundered the national wealth while governments badly need resources to reconstruct and rehabilitate their societies." A straight forward

\footnotetext{
${ }^{1}$ Paiman Ramazan Ahmad, PhD Candidate-National University of Public Service-Faculty of Political Sciences and Public Administration- Budapest-Hungary, Affiliation: University of Raparin Email: Paiman.ahmad.ramazan@uninke.hu, Paiman@raaprinuni.org, Paiman.ramazan@gmail.com
} 
definition is given by Danish International Development Agency (DANIDA), which defines corruption as the "misuse of entrusted power for private gain" that corresponds to the concept of corruption in the Danish Penal Code and in international anti-corruption conventions. CleanGovBiz (2014) highlighted corruption "as one of the main obstacles to sustainable economic, political and social development, for developing, emerging and developed economies alike." Argued by Transparency International (TI) "when essential institutions are weak or non-existent, corruption spirals out of control" such as the case in "Iraq, Afghanistan and Somalia."[BBC, 2009]. Consequently, "rules and regulations are circumvented by bribes, public budget control is undermined by illicit money flows and political critics and the media are silenced through bribes levering out democratic systems of checks and balances."'CleanGovBiz, 2014]. This study is about corruption in a specific sector, which is the source of income and economic well-being of the entire community in Iraq. Therefore, combating corruption in Iraq has recently been the main issue of the government in power. Even though the Iraqi government was late in boarding the ship of egovernment due to the chaos the country is in since 1980s. Admitting that corruption is a serious threat to economic development and stability in Iraq and elsewhere, bearing in mind that corruption creates a cycle that would make sure that benefits are concentrated on these small sector of the populace. [Balboa\& Medalla, 2006]. Responding to this need, "corruption is nurtured by politicians who coddle supporters and followers, who in turn pressure them to engage in corruption to spread the benefits of a corrupt regime." [UNDP, 2004]. Accordingly, corruption thrives when government policies for transparency and integrity are poorly designed, like in Iraq. Governance by disclosure has become the heart of the global governance trend, in transparency the government's role is asserted to clear corruption in the natural resource sector, a sensitive question is, why corruption is a pervasive phenomenon in developing rentier states? Theoretically governments abundant with natural resources pretend that they fight corruption, but in practice corruption alarms in those countries.

\section{1 "Theory of War Trap and Corruption"}

The enforcement of sanctions in 1990 under the Security Council Resolution 665, till, lifting of the sanctions following the Iraqi invasion in 2003 under the UN Security Council Resolution 1483, the process has created the climate for systematic corruption. [CNN, 1999]. In the broadest sense, for the economic coercion to work, target elites must suffer as much as the target population. In parallel to this, sanctions permit target regimes to strengthen state control over the economy, especially if the target regime is authoritarian; this was typically true for the Iraqi Saddam Hussein's regime. [Drezner,1999: 13]. According to the economic argument, waging war and military intervention is very expensive as it was for the United States in the case of Iraqi intervention, yet the truth is the economic spill-over is much more for the Iraqis compare it to the Americans, since for almost 3 decades since the invasion, the Iraqi economy is maneuvered by high levels of corruption. According to this logic, costly sanctions have created a suitable climate for corruption to spread in Iraq since 1990. As, Keohane (1993) has well championed the economic coercion, since imposing sanctions and economic leverage is used to extract political concessions," but in Iraq the Ba'ath regime instead of concession had tried to get more funds by corrupting the economy and the high governmental officials. This has helped the government to power direct the petroleum sector illegally to target the benefits of the resources for a particular group. In the post invasion era, the logic of corruption was well coded, and the networks were present. It is claimed that "each war is a unique event with its own idiosyncratic causes and its own idiosyncratic consequences." [De Mesquita, 1981:3]. In a sense, Saddam Hussein is well-known for his military and authoritarian leadership in the Middle East and globally, his image is known as a tyrant who devastated the economy of three states including Iraq, Iran and Kuwait. Since, the Iraqi economy and the 
population suffered from the eight years' war with Iran, plus the invasion of Kuwait, the embargo and the sanctions all in all has devastated the economy. The economic consequences of wars and economic blockade has further framed the economy in a Prebendalism system that has further deteriorated and crippled the public well-being of Iraqis and the misuse of revenues in favor of government supporters. Referring to Hussein's attempt in singling out a specific program during the humanitarian emergency October 1994, it decided to favor the military, police, security and other elite forces with special monthly allowances and other privileges. Some of the privileges were extended to civil and military pensioners. While these privileges cover some 3.5 million people the other 17.2 million Iraqis, or 83 percent of the population was left out of the program of privileges [FAO 1995: 7-8 and 19]. In sum, a clientelist regime, in a predatory system the public and private resource are melded and public office serves as a means for the creation of private wealth. [Alnasrawi, 2000]. Broadly, clientilism and prebendalism is at stake in the absence of active media, high public awareness, and absence of E-government in Iraq. In essence, Prebendalism was first addressed by Richard Joseph to describe a central feature of Nigerian politics. In examining this unusual term, this phenomenon is widespread in most rentier economies, especially in the case of poor governance and dysfunctional system such as in Iraq. Remarkably, Joseph envisioned "prebendalism" as "the state offices are regarded as prebends that can be appropriated by officeholders, who use them to generate material benefits for themselves and their constituent and kin groups. [Joseph, 2013]. It could be noted that the Iraqi corruption did not start yesterday; it started almost 35 years ago, and sparkled in the $90 \mathrm{~s}$, as a need to feed the government's military hunger for the Ba'ath regime's survival. In conceptualizing prebendalism in Iraq, in practical term, it is comparable to the similar situation in Nigeria, to begin; the Iraqi political landscape as a fragile state is featured as a short time-horizon in which resources accruing to the office can be diverted for personal and related uses, or for the capital accumulation, which it facilitates.

In the current situation with the absence of a competitive government, and lack of good governance, the Iraqi economy is floated with prebendalism, for understanding prebend. In their contribution Adams and Brock (2004) argued that conglomerate giants were portrayed as superior to decentralized capital markets in allocating financial funds among alternative uses and in ensuring that these funds would flow to their most socially desirable uses. [p.71]. Referring to transparency in the absence of E-Government in Iraq, the entire system, and revenues are poorly generated, for example; recruitment, procurement, employment are oriented in more patrimonialism base, like Max Weber states "the most universal form of human political interaction is a patron-client relationship in which a leader exchanges favors in return for support from a group of followers." [Joseph, 2013]. There is a lack of literature on Prebendalism and Patronage in regard to Iraq and the use of natural resources, adding Van De Walle's (2007) contribution in addressing patronage as "the practice of using state resources to provide jobs and services for political clienteles." On the basis of this analysis, corruption alarms as a consequence of state dynamics in the Iraqi extractive industry, the misuse of revenues by corrupted politicians marginalize the Iraqi public. According to, information during the interim government period in Iraq, the quest for "greater transparency in oil governance should start with oil flow metering, a public consultation on oil policy, and the publication of all revenues derived from the oil sector. Strong accountability mechanisms are also required, through independent media, auditing and judiciary." [Le Billion, 2005]. In fact, petroleum sector was hampered by the central role of Saddam's regime, adding, Sayne and Gillies (2016) pointed out that "between 1996-2003, certain traders taking part in the United Nations monitored Iraq Oil-for-Food Program (OFFP) negotiated secret side payments to the Iraqi government in exchange for the oil they received. Actors involved in the scheme used shell companies, disguised corporate ownership, and offshore banking services to facilitate the payments." As a consequence, the Iraqi government was able to generate over \$ 1.8 billion for Saddam Hussein's regime. This 
shows how governments can monopolize even international organization such as the UN for maximizing their governmental interest from their resources. Uprooting corruption in Iraq needs a strong will of the government, to combat the networks of corruption in the public sector especially in the energy sector. According to Cockburn (2009) the UN sanctions imposed a tight economic siege and were designed to keep oil revenues out of the hands of the ruling elite. In the light of this, in 2004-5 the government allocated \$1.3billion for weapons purchases." It is claimed that war has created a power vacuum for spreading corruption, and lack of checks and balances has further deteriorated the situation. In a similar case, during the 2004-7 in which $\$ 600$ million in food rations supposedly sent to Anbar and other Sunni provinces at a time when those places were partially controlled by the insurgents, due to violence there is no clue that goods paid by the government had ever been delivered. Combined with this, Cockburn further emphasized the effect of the sanctions sow the seeds of corruption, as the Iraqi regime was in economic stagnation, currency collapsed, thus government officials found a way of evading sanctions to accumulate resource illegally to generate funds for government survival. In responding to need, government officials in Iraq during the Ba'ath regime for the first time involved in a systemic corruption, hence "the men who orchestrated these black market deals under Saddam Hussein found they could quickly establish the same sort of corrupt relations with post-Saddam government." [Cockburn, 2009]. The rising of new public administration and E-Governance for Iraq was in a period where the level of corruption and poor governance prevailed in the system and it has still remained very high. Since the sanctions, Iraqi oil sector was marred by political and economic strife in particular because of a 10 years history of the corrupt military regime. Looting of the public treasury is the serious concern for the new government of Haider Al-Abadi, who has committed to uproot corruption and grappling kleptocracy, which is facilitated by sectarianism and power sharing, and struggling to reform a political system beleaguered by corruption. In respond to reforms his recent effort was a contested cabinet reshuffle aimed at depoliticizing governance. [Karam, 2016]. Arguably, corruption in extractive sector is quite different, in line with this; EITI might be enacting disclosure, transparency and accountability, yet cases such as UNAOIL company huge bribery scandal give a brief on how high level officials are involved to gain the big shares from contracts and projects. Indeed, a case such as UNAOIL which has been on social media needs a sound governmental response. [Baumann et al, 2016]. Indeed, cash flow from energy sector is very big and it represents a very serious temptation to corruption. The lack of e-government complicates the process of revenue flow in Iraq and limits the government capacity in avoiding the abuse of revenues for political and individual gains in general. In fact, corruption in the energy sector is endogenous since the sector is monopolized by the Iraqi government, while the exogenous part is from foreign oil and gas companies, which desire to make huge gains from the contracts and projects. In this context, for the Iraqi government to control corruption is pursuing zero tolerance policy to combat corruption within the sector, by uprooting endogenous corrupt practices in the energy industry. In tackling corruption, for the efficacy of e-government development, USAID (2007) in the list of top "10" database driven E-Government initiatives, which supposed to be prepared after long in depth consultation with a selected group of Government of Iraqi Chief Information Officers (CIOs), ten ministries and entities of the Iraqi government are places as the top priority, while Ministry of oil "energy sector" is not listed," the objective of excluding energy sector is very odd, since petroleum products makes a variety of useful contributions to the Iraqi economy.

Based on the same USAID 2007-2010 strategy for E-Government, it was expected that the part of the Ministries involved will achieve the desired results of delivering at least $50 \%$ of these projects within their estimated time frame, whereas after 6 years in post planned strategy even $10 \%$ is not achieved in E-Government in Iraq yet. Besides, in mentioning the benefits of E-Government in Iraq nothing is mentioned about "integrity, transparency, accountability, corruption" which conveys that 
E-Government strategy was only a starter. One of the most serious barriers to E-Government in Iraq besides; security, lack of hard and soft capital, "the silo" agency-centric approach of government, where information sharing is limited, thus for E-Government transformation to success, a shift will need to occur at every level of government in Iraq. (USAID, 2007). In the global e-Government indexes, the Iraqi government performs poorly as being counted as a rich country besides, in some indexes for ICT Iraq has no existence such as ICT Development Index 2016. ${ }^{2}$

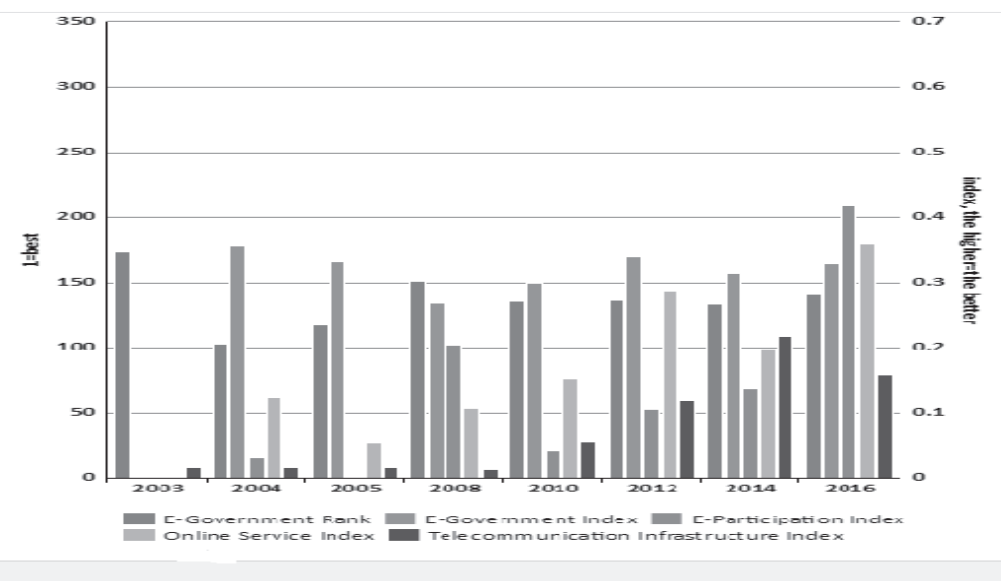

Figure $1^{3}$

\subsection{Corruption in the Extractive Industry "Iraq"}

Corruption is generally harmful to any community and to economics; in fact corruption in the extractive industry is very sensitive, it is not like a tax or a fee it is more than that. In the case of the resource abundant countries the rents from natural resource are the source of fueling the economy like in Iraq. In developing resource abundant countries in certain cases the rents from resources are not channeled properly to the economic growth and welfare of the citizens instead, it goes into private pockets or to officials who are involved in the extractive industry. In economic terms, corruption in extractive industry means exhausting the scare resources for unproductive deeds similarly means "economic development is difficult in countries where corruption undermines the development of fair market structures and distorts competition.”[Hama, 2016]. The Transparency International /Corruption Perception Index (CPI), ranked Iraq 161/168 countries with the score of $16 / 100$ which shows that Iraq is in high level of corruption scale. According to Business AntiCorruption country profile for Iraq, "corruption in the public and private sectors is a serious challenge for business in Iraq. Besides, "companies can expect to contend with several forms of corruption, including a deeply entrenched patronage network, and investors may face pressure to take on well-connected local partners to avoid bureaucratic hurdles.“[Iraq Corruption Report, 2015].

The factors that affect mitigating corruption are many in any country context, in getting to analyze why industrial countries are less corrupted comparing them to highly corrupted resource abundant

\footnotetext{
${ }^{2}$ See: ICT Development Index 2016 at: http://www.itu.int/net4/ITU-D/idi/2016/\#idi2016map-tab.

${ }^{3}$ Source: https://knoema.com/UNEGR2015/un-e-governmant-ranking-2003-2016? country=1001260-iraq
} 
countries. In available literature few factors are seriously discussed and investigated; including type and structure of the economy, level of income, institutional capacity, and type of governments, culture, yet incentives for corruption are key drivers for stimulating the process. An appropriate approach that can combat corruption effectively is E-government and openness, which pushes government towards transparency and effectiveness in the natural resource governance. Comparing extractive industry to the other industries it is more sensitive, and it is harder to avoid corruption, because this sector is governed by the government institutions and the high officials. In the rentier states, Carmody (2009) contends in a "win-win bonanza" where foreign firms benefit from bad governance through securing favorable contract terms by networking with domestic political elites who serve as gatekeepers from natural resource extraction. Accordingly, "the extractive industry is ailing the economy of Iraq, and escaping the natural resource curse is hard for a weak state, improving economic performance in a single commodity driven country is highly critical, the Iraqi main natural resource is oil and that is the single commodity that fuels the economic sector, besides natural gas. In fact, Iraq is more prone to corruption in petroleum sector compare it to the rest of the other sectors, this does not mean that corruption is lower, but extractive industry generates huge money, and the rents are under the control of government. In this regard, "corruption has been cited as one of the most prevalent and persistent challenges in enhancing economic growth and improving the quality of life of citizens across the globe.'[Mistry\& Jalal, 2012].The lack of open government in Iraq has led to further devastation of the economic system of Iraq, the petroleum sector is an opportunity for the future generation and this vision can only be guaranteed by enforcing a strong E-governance system in the sector. As, the extractive industry "is regarded as the country's key source of financial resources and the driver of economic and national development."[EITI, 2014:12]. Adding to corruption from Peter Eigen chairman of Transparency International, "corruption is a major cause of poverty as well as a barrier to overcoming it."(Transparency International's (TI) Corruption Perception Index 2005). Addressing Iraq as a country suffered for more than two decades from security and ethno-sectarian, Iraq has worst performance in the governance and economic growth, as Prime Minister Al-Maliki in 2006 defined corruption as the threat to state building and the nation's second insurgency. [SIGIR, 2013].

The public of Iraq has been pressuring the government for serious reforms for eradicating the systematic corruption, which pervades the Iraqi economy for years. The E-Government aims for more transparency and accountability of the government. The quota system in the Iraqi new cabinet under Al-Abadi faces a systemic crisis, in which the quota system is a structural problem in the system. With the economic crisis undermining the power of the government and the security crisis accumulating since 2014, Moqtadar Sadr was a stimulator and champion for triggering change in the government and presenting the anger of the public for anti-corruption on July 31, 2015. While, Abadi hinted in his speech that Sadr's behavior is not in line with reform, as he has no right to claim that he is defending reform. Furthered, he added that "when someone's institutions and associates are plagued by corruption, then he cannot claim to be fighting corruption, and Sadr is part of the government. [Saadoun, 2016]. In the vacuum of E-Government in Iraq, for the extractive industry transparency, it is necessary to think of media as a toolkit for transparency and openness. Thus, transparency as media openness can contribute to anti-corruption efforts by uncovering cases of misappropriation and nepotism. The Iraqi chronic corruption "exists at the highest levels of government and is sustained by widespread nepotism and clientelism, the climate of fragile institutions in Iraq has encouraged militia and political leaders to create their own support base by redistributing jobs and public funds. Thus, lack of open system, especially e-government "the patronage based on party, family or community determines who gets a job. Indeed, the lack of egovernment led to embezzlement of resources, funds, and abuse of the public interest. [Al-Hawat, 2016]. 


\section{Iraq towards E-Government in Extractive Industry the Role of Extractive Industries Transparency Initiative (EITI)}

In accordance with the role of the Extractive Industries Transparency Initiative (EITI), the role of EITI is defined in setting "global standard for transparency in the oil, gas and mining industries. The EITI's objective is to achieve a standard for review, analysis and publication of revenue flow between extractive industry companies and governments. In this manner, EITI aims to promote transparency in order to prevent corruption, and to provide citizens with a basis for demanding a fair use of revenue. Importantly, Iraq made a commitment under "the Prime Minister Nouri AlMaliki in May 2008 to initiate stepping to EITI commitment for enforcing transparency and accountability in the extractive industry in Iraq, in two years by February 2010, Iraq has become candidate in EITI." [EITI, 2014]. The mission of EITI is crucial for Iraq, as for the first time since the discovery of petroleum sector, the Iraqi government accepted to publish data, yet disclosing the data on revenues does not mean Iraq is free from corruption. The EITI is successful in making revenues more transparent and this impact transcends into other areas of the economy. [Oge, 2016]. Apparently, EITI supports the dissemination of information and data from the government, this promotes the government towards openness and pursuing E-Government model for Iraq in the future. The Iraqi government commitment to openness is yet very weak generally in the public sector. However, in petroleum sector, government is more committed especially with EITI, which creates doubts for scholars and citizens. Thus, there is a serious debate on whether Iraq is really transparent and accountable drawn from EITI reports, or it is part of transparency. According to EITI "the government of Iraq committed itself to publishing all revenues from its export sales from the oil sector. In addition, international companies buying oil from Iraq shared the same commitment of publishing what they have paid to the government."[EITI, 2014:12]. In line with this, EITI (2015) brief has emphasized that "Iraq has gone beyond basic EITI reporting requirements by including reconciled oil sales and figures in its reports." While, the Natural Resource Governance Institute (NRGI)'s Resource Governance Index gives Iraq a score of 9/100 for the enabling environment, highlighting the lack of an open budget, low levels of accountability, government effectiveness and rule of law.

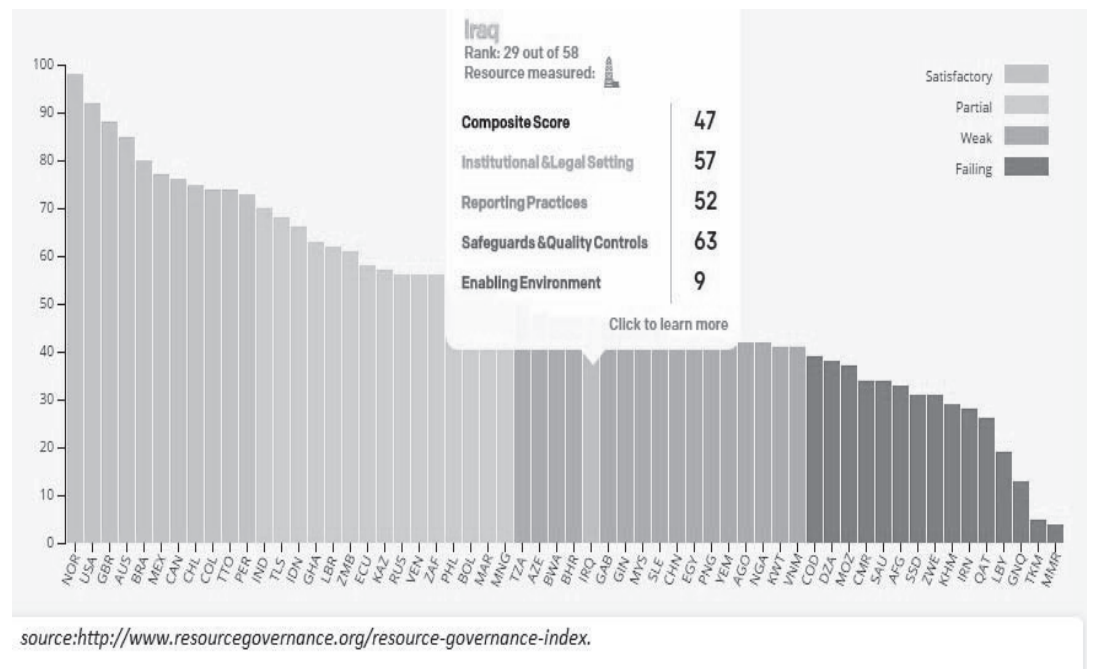

Figure 2 
In the rentier states it is difficult for the public to hold the governments accountable, because of disclosure of rents from natural resources. Recognizing, "Publish what you pay" campaign was very interesting for transparency and accountability, because both government and companies were to publish their information on payments to each other and for the public. Importantly, PWYP can help provide a double-entry check on government revenues, since companies' reported payments should match governments reported natural resource revenues from companies (including stateowned companies). [Palley, 2003]. The right to get access to information in Iraq is still under the government's control, and the right of citizens to access information is not considered as a mechanism for creating transparency especially in the extractive industry. Protecting the right of citizens is the responsibility of the government, commitment to open government means government advocates the freedom of information to citizens regardless of the sector, but there are many controversies about petroleum sector information, petroleum sector has secrecy history in Iraq. The institutional infrastructure for open government is vulnerable to political and ethnic tension in Iraq, drawing on freedom of information in Iraq is more related to the media, the main attempt towards open governance and transparency is made in July 2009, "the Journalistic Freedom Observatory in Iraq called upon the Constitutional Review Committee of the Council of Representatives, and The Office of Constitutional Support (OCS) of the UN Assistance Mission for Iraq (UNAMI) to conclude constitutional provisions that grant the right of individuals to access information held by the state." [WNA, 2009]. In responding to "the need of access to information and openness, Tamken, a group of experts, journalists, and academics, drafted the "Information Access Right Draft Law” in late 2009. [Article 19 Global Campaign for Free Expression, 2010]. Article 19 commented on the draft law and suggested a number of amendments to ensure the bill's compliance with international standards. Few important amendments were proposed since some crucial provisions were missing. Such as; the Draft Law does not refer to "public interest." In line with this, few important recommendations are emphasized, including; "guarantying the right of everyone to access information, securing the right to get information, availability of information for the public, in reviewing the disclosure of information private bodies to do independently of government. Insofar, the right of access to information is fundamental human rights right, which is stipulated in "International Human Rights Law and the Anti-Corruption Conventions that signed by the Iraqi government. Overall, the aim of this law is to promote "openness in the government." [Iraqi Constitution/article 19, 2005].

\subsection{E-Government as a tool for anti-corruption in Iraq}

According to UNDP (2006) Electronic Government (e-Government) refers to government's use of ICTs to work more effectively, share information and deliver better services to the public. Moreover, a well-planned e-government strategy can make leaps into building a more efficient, accountable and transparent government. Accordingly, combating corruption is complemented with: strategies to reduce corruption include:

- $\quad$ Prevention: reform administrative procedures, accounting and procurement practices.

- $\quad$ Enforcement: institute proper record-keeping and put in place an effective system of surveillance and enforcement.

- $\quad$ Access to Information and Empowerment: promote access to information and enable public and media oversight.

- $\quad$ Capacity Building: strengthen governance systems and processes, and provide training. 
In the light of this, E-governance is already being used around the globe to lower instances of corruption. Moreover, ICTs are mainly used by governments for ridding the public sector of corrupt practices, and it urges transparency and accountability by encouraging the reporting corruption. [GTC, 2015]. Accordingly, E-Government can cut corruption, and increases transparency and access to information, the digital government performance in Iraq is still at the beginner phase. When can e-government be effective in the case of a fragile state like Iraq, as Kjar (2004) pointed out that governance in weak states is often an uphill task, economic governance in these states is about managing institution that have often developed in such a way that they constitute obstacles to development. In fact, using ITC since early 1990s got serious importance from the private sector to deliver service to customers effectively and efficiently, thus governments considered this opportunity to install e-government to strengthen the public sector and electronic service delivery, as an easy channel of communication with citizens, e-government has targeted to enhance service to business and citizens, and promote participation and democracy. [Rowley, 2011]. Indeed, Iraq is one of the developing resource abundant countries that have the dubious increase of corruption with each year passing. Comparing Iraq as an abundant natural resource country to the Asia-Pacific region, which perform much better in delivering services electronically and adopting e-government, Iraq is far lagging behind in e-governance. In this way, Iraqi E-governance and E-government in fact has the different historical background, since 2003 Iraq is open to "ICT" and modern technology "for the public" since the Iraqi Ba'ath regime has restricted the use of ICT till 2003. Thus, Iraqi exposure to e-government is a decade late compares it to the rest of the world. The first new Iraqi interim government in 2004 has signed a Memorandum of Understand between the Iraqi Minister of Science and Technology and the Italian Minster for Innovation and Technology. According to the Memorandum, the Italian Government commits to provide technical and financial assistance for the construction of an Intranet linking the ministries of the new Iraqi Administration and built an e-Government project. (Al- Dabbagh, 2011). Noted, it is known that the first initiative was in 2004, in which the Iraqi institutional capacity was entirely collapsed due to the wars, and security, as a result the project failed. Once again the United States Agency for International Development (USAID) and the Iraqi Ministry of Science and Technology put a strategy from 20072010 for developing the Iraqi electronic government, from USAID (2007), accumulated that "the entire process needs to be carefully supported, resourced and funded." Besides, Iraq needs to coordinate its e-government strategy with project implementations in order to compete in the region, and to be recognized as a country serious about the public sector reform.[USAID, 2007].

During the 23 years since the Iraqi liberation, the government is floated with websites and the goal is not to reduce the paperwork, yet approaching a paperless administration is not the target for the government in practice yet. Adding, it is crucial to realize why the Iraqi government failed, since the E-Government project was supported by the US government and Italy initially? Indeed, mentioning the reasons of the Iraqi E-government failure is centered on the lack of proper infrastructure, human capital, and resources, yet the country's situation is peculiar with an ongoing crisis and chaos, which has paralyzed the government attempts for innovation and ICT development. Basically speaking, the phases of adopting E-government is proposed in 2002 by the United Nations and the American Society for Public Administration, the model consist of five stages, including: the "emerging state: in this stage an official online government presence is formed, in the following stage it is "enhanced "here the number of government sites increases and become more dynamic. The "interactive" stage is more progressive in fostering interaction of users and the officials through the Web. Then in the "transactional" stage, the users have ability to make online transactions. Lastly, the "seamless" stage which makes the integration of electronic service across the government agencies possible. [Yildiz, 2007]. To evaluate the Iraqi performance in Open Government, open data in the frame of E-Government, it is crucial to look the E-Government 
Readiness Index; which is among the most accurate indices in the world for tracking the aspects of e-governance globally. In more detail, this index assesses the e-government readiness of the 193 selected countries, according to a quantitative composite index involving the website assessment, telecommunication infrastructure, and human resource endowment. Considering the data for Iraq in 2003 including; E-Government was (0.0000), E-Participation Index was (0.0000), and EGovernment Development Index was (0.0000).

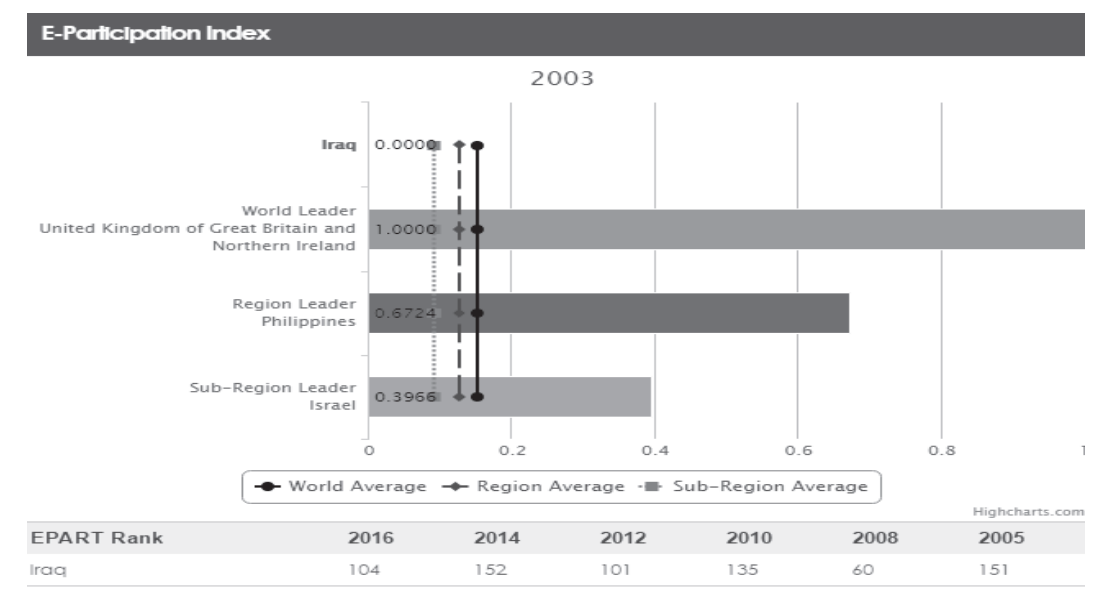

Figure $3^{4}$

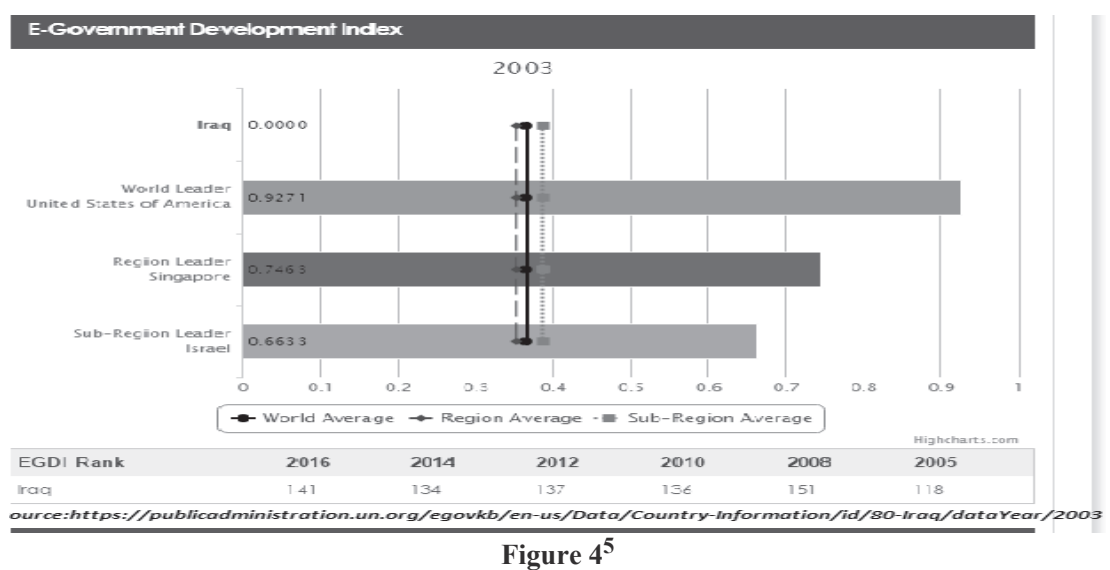

In the Revenue Watch Index country ranking, Iraq stands as the first in partial revenue transparency, with a score of 63.8 .

\footnotetext{
${ }^{4}$ See: https://publicadministration.un.org/egovkb/Data-Center.

${ }^{5}$ See: https://publicadministration.un.org/egovkb/Data-Center.
} 


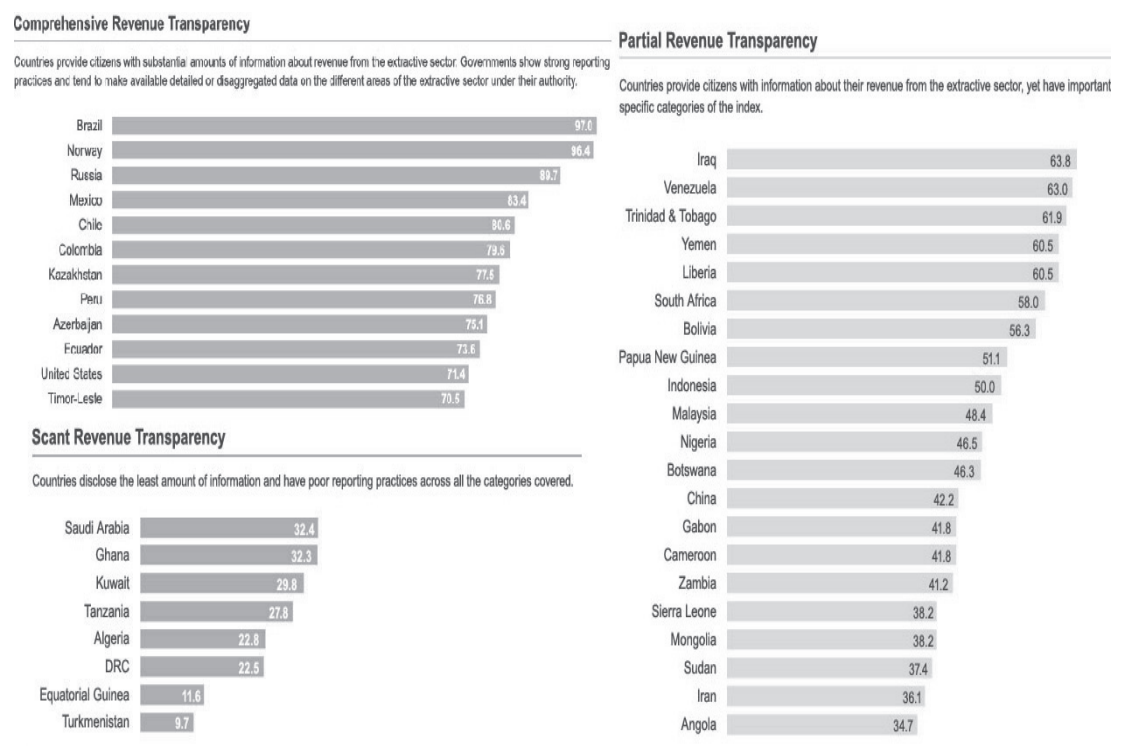

Figure $5^{6}$

\section{Conclusion}

The E-government implementation in Iraq has encountered serious milestones; as Iraq encounters political, economic, security, ethnic tension and social challenges, including the lack of infrastructure and technological architecture, and human capital, therefore; to the date the government of Iraq is not able to install E-Government properly, and Iraq is still in the early stages of E-Government development process. In fact, E-Government as a serious measure can reduce corruption especially in the energy sector, which is the source of cash flow that fuels the Iraqi economy. Hence, for the government to protect the public good, cutting corruption and preventing the abuse of public funds is only safeguarded by pursuing E-Government and a transparent approach in the extractive industry in Iraq. It is crucial to remember that the Iraqi membership in EITI is important for the government, the public and globally, because EITI was the first attempt for Iraq for reporting and disclosure of data on revenues generated from energy sector.

\section{References}

[1] AARON, S. and GILLIES, A.: Initial Evidence of Corruption Risks in Government Oil and Gas Sales, EITI Briefing/ Natural Resource Governance Institute, June, 2016, p.10.

[2] ALNASRAWI, A.: Iraqi: economic embargo and predatory rule, CASI, May, 2000, available online at: http://www.casi.org.uk/info/alnasrawi9905.html. (Accessed on December 12, 2016).

[3] HAMA, A.: adhere to laws to weed out corruption, the National, August 10, 2016, available online at: http://www.thenational.com.pg/adhere-to-laws-to-weed-out-corruption. (Accessed on December 28, 2016).

\footnotetext{
${ }^{6}$ See: http://www.revenuewatch.org/rwindex2010/rwindex.html.
} 
[4] KJAR, A.M.: Governance, key concepts, Malden/MA. USA, Polity Press, 2004, p. 140.

[5] Anti-corruption, UNDP February 2004, cited in: Jenny,Balboa.,\&Erlinda, M. Medalla. anticorruption and governance: the Philippine experience, APEC Study Center Consortium Conference, Ho Chi Minh City, Vietnam May, 2006, 23-24.

[6] Article 19 Global Campaign for Free Expression, Legal Analysis of draft law on the Right to Access Information, January 2010. Available at: http://www.article19.org/pdfs/analysis/iraqanalysis-of-draft-access-to-information-law.pdf.

[7] BBC, War-torn nations 'most corrupt, November 17, 2009, available online at: http://news.bbc .co.uk/2/hi/8363599.stm. (Accessed on December 15, 2016).

[8] BUENO DE MOSQUITA, B.: The war trap, New Haven, the United States of America, Yale University Press, 1981, p. 3.

[9] CARMODY, P.: Cruciform sovereignty, matric governance and the scramble for Africa's oil: Insights from Chad and Sudan, Political Geography. Vol. 28. Issue 6. 2009.

[10] CleanGovBiz Initiative, the rationale for fighting corruption, Organization for Economic Cooperation and Development, Paris France, 2014.

[11] CNN, Sanctions send Iraq on downward spiral, July 12, 1999, available online at: http://edition.cnn.com/WORLD/meast/9907/12/iraq.sanctions/. (Accessed on December 27, 2016).

[12] Corruption Perception Index, 2015, available at: https://www.transparency.org/cpi2015.

[13] DREZNER, D. W.: The sanctions paradox, Cambridge, UK, Cambridge University Press, 1999, p.13,.

[14] EITI Brief, the EITI, NOCs \& the first trade, issued by EITI International Secretariat, Oslo, Norway, 2015, p.10.

[15] EITI Iraq Oil Revenues 2012, oil export, local consumption and field development, December, 2014.

[16] FAO/World Food Program, FAO/WFP Crop and Food Supply Assessment Mission to Iraq, Rome, FAO. 1993. In Abbas, Alnasrawi, Iraqi: economic embargo and predatory rule, CASI, May, 2000, available online at: http://www.casi.org.uk/info/alnasrawi9905.html. (Accessed on December 12, 2016).

[17] GTC, how ICT is cutting out corruption, February 25, 2015 available online at: http://blog.thegtcgroup.com/how-ict-is-cutting-out-corruption. (Accessed on December 10, 2016).

[18] BAUMANN, N., AKBAR, S.A., SCHULBERG. J. and BLUMENTHAL, P.: Unaoil's huge new corporate bribery scandal explained, The Huffington post, March 30, 2016, 
available online at: http://www.huffingtonpost.com/entry/unaoil-scandalexplained_us_56fbd2f 0e4b0daf53aee0cff. (Accessed on December 10, 2016).

[19] Iraq Corruption Report, Iraq, May, 2015. Available online at: http://business-anticorruptioncom/country-profileiraq. (Accessed on December 11, 2016).

[20] JAMSHED, J.M. and ABU, J.: An empirical analysis of the relationship between egovernment and corruption, the International Journal of Digital Accounting Research, Vol.12, pp (145-176), 2012, available online at: http://www.uhu.es/ijdar/10.4192/1577-8517v12_6.pdf.

[21] BALBOA, J.,E., MEDALLA, M.: Anti-corruption and governance: the Philippine experience, APEC Study Center Consortium Conference, Ho Chi Minh City, Vietnam May 23-24, 2006.

[22] JOSEPH, R.: Epilogue, the logic and legacy of prebendalism in Nigeria, in: Wale, Adebanwi., \& Ebenezer, Obadare. (eds.). Democracy and Prebendalism in Nigeria, Critical interpretations, New York, the United States, Palgrave Macmillan 2013.

[23] KEOHANE, R.: Institutional theory and the realist challenge, after Cold War, in David Baldwin, ed. Neorealism and neoliberalism. The Contemporary Debate, New York, Colombia University Press, 1993.

[24] KEREM, O.: Which transparency matters? Compliance with anti-corruption efforts in extractive industries, Resource Policy/ Elsevier, 2014, pp, 41-50.

[25] Weber M., RICHARD, J.: Prebendalism and dysfunctionality in Nigeria, Africa Plus, July 26, 2013, available online at: https://africaplus.wordpress.com/2013/07/26/prebendalism-anddysfunctionality-in-nigeria/\#_edn14. (Accessed on December 14, 2016).

[26] Memorandum on the Draft Access to Information Draft Law of Iraq - ARTICLE 19, London, 2010 - Index Number: LAW/2010/01/Iraq, available online at: https://www.article19.org /resources.php/resource/331/en/iraq:-constitution.

[27] AL-DABBAGH, M.: Electronic Government in Iraq: challenges of development and implementation, Project work, summer, Swedish Business School at Orebro University, 24 August, 2011.

[28] SAADOUN, M.: Iraq's civil movement breaks Sadr Protests, Al-Monitor, July 31, 2016, available online at: http://www.al-monitor.com/pulse/originals/2016/07/sadrists-protestscivil.html. (Accessed on December 24, 2016).

[29] KARAM, P.: Oil identity politics and the struggle for reform in Iraq, April 6,2016, Natural Resource Governance Institute, available online at: http://www.resourcegovernance.org /blog/oil-identity-politics-and-struggle-reform-iraq. (Accessed on November 17, 2016).

[30] COCKBURN, P.: Why Iraq is now the most corrupt country on the planet, June 29, 2009, available online at: http://www.counterpunch.org/2009/06/29/why-iraq-is-now-the-mostcorrupt-country-on-the-planet. (Accessed on December 24, 2016). 
[31] LE BILLION, P.: Corruption, reconstruction and oil governance in Iraq, Third World Quarterly, Vol. 26, No. 4/5, 2005.

[32] ROWLEY, J.: E-Government stakeholders - who are they and what do they want? International Journal of Information Management, 2011, pp,53-62.

[33] Al-Hawat, S.: Walking a tightrope: the dilemma of the anti-corruption campaign in Iraq, Guacu, March 9, 2016, available online at: http://weareiguacu.com/walking-a-tightrope-thedilemma-of-anti-corruption-campaign-in-iraq. (Accessed on December 27, 2016).

[34] Special Inspector General for Iraq Reconstruction (USA), Final Report - March 2013 available at:http://www.sigir.mil/files/learningfromiraq/Report_-March_2013.pdf.

[35] The World Bank, Helping countries combat corruption, the role of the World Bank, September, 1997.

[36] PALLEY, T.I.: Lifting the natural resource curse, Global Policy Form, December, 2003, available online at: https://www.globalpolicy.org/the-dark-side-of-natural-resources-st/waterin-conflict/40112.html. (Accessed on December 17, 2016).

[37] UNDP, fighting corruption with e-Government application, APDIP, e-Note 8, 2006.

[38] United Nations Convention against corruption, United Nations Office on Drugs and Crime, United Nations, New York, 2004.

[39] United Nations E-Government Survey, E-Government in Support of Sustainable Development, United Nations Department of Economic and Social Affairs, 2016, p.103.

[40] USAID, Government of Iraq E-Government strategy 2007-2010, USAID-Funded Economic Governance II Project Bearing Point Inc, 2007.

[41] USAID-Funded Economic Governance II Project Government of Iraq e-Government Strategy, June 20, 2007

[42] VAN DEL. WALLE, N.: The path from neopatrimonialism: democracy and clientelism in Africa today, working paper series No.3-07, Mario Einaudi Center for International Studies, 2007.

[43] Adams, W. and Brock, J.W.: The bigness complex, industry, labor and government in the American economy, (2 ${ }^{\text {nd }}$ ed), California, Stanford University Press, 2004, p.71.

[44] WNA news, the Committee on Constitutional Amendments and internationalists experts are required to approve the right of access to information, 2009, available online at: http:/www .wna-news.com/inanews/news.php?item.24722.7 (Arabic, accessed on March 02,2017)

[45] LEOPOLD, W.: Is prebendalism a global phenomenon today? January 17, 2014, available online at: https://news.northwestern.edu/stories/2014/01/is-prebendalism-a-globalphenomenon-today. (Accessed on December 26, 2016). 
[46] YILDIZ, M.: E-government research: reviewing the literature, limitations, and ways forward," Government Information Quarterly, Vol. 24, 2007, pp. 646-665. 